\title{
CORRIGENDA
}

\section{Feeding ancient cities in South Asia: dating the adoption of rice, millet and tropical pulses in the Indus civilisation CORRIGENDUM}

Cameron A. Petrie, Jennifer Bates, Thomas Higham \& Ravindra N. Singh

Published by Cambridge University Press, 21 November 2016.

In the article by Petrie et al. (2016), the funding information supplied was incorrect. The correct details are as follows:

The paper presents material that was excavated and analysed as part of the multidisciplinary 'Land, Water and Settlement' project, which ran between 2008 and 2014 under the co-direction of C.A. Petrie (Cambridge, UK) and R.N. Singh (BHU, India) (http://www.arch. cam.ac.uk/rivers/). The writing of the paper was carried out as part of the 'TwoRains' project (https://www.arch.cam.ac.uk/research/projects/two-rains), which is running from 20152020 and is the successor to 'Land, Water and Settlement'. The research of the 'Land, Water and Settlement' project was made possible thanks to a Standard Award from the UK India Education and Research Initiative, and funding from the British Academy's Stein Arnold Fund and International Mobility Scheme, the Isaac Newton Trust and the McDonald Institute for Archaeological Research. Permission to carry out the excavations conducted by the project, and to export samples for analysis, was granted by the Director of Exploration and Excavation, Archaeological Survey of India. The radiocarbon dating was made possible thanks to grants awarded by the Natural Environment Research Council (NERC) funded NERC Radiocarbon Facility (project numbers NF/2009/2/7 and NF/2013/1/6), and was overseen by T. Higham. During her PhD research, J. Bates was supported by an Arts and Humanities Research Council studentship, and was awarded funding for fieldwork by Trinity College and the Division of Archaeology, Department of Archaeology and Anthropology, University of Cambridge. The 'TwoRains' project is supported by funding from the European Research Council under the European Union's Horizon 2020 research and innovation programme (grant agreement number 648609). We would also like to thank C. Broodbank, M.K. Jones, C. Lancelotti, M. Madella, T.C. O'Connell and L.R. Weeks for providing useful comments on drafts of the manuscript.

\section{Full citation}

Petrie, C., J. Bates, T. Higham \& R.N. Singh. 2016. Feeding ancient cities in South Asia: dating the adoption of rice, millet and tropical pulses in the Indus civilisation. Antiquity 90: 1489-1504.

https://doi.org/10.15184/aqy.2016.210 